\title{
炭疽菌と生物兵器
}

牧 野 壯一

帯広畜産大学畜産学部獣医学科家畜微生物学教室（干 080-8555 北海道带広市稲田町西 2 線 11）

\section{Anthrax as a Biological Weapon}

Souichi MAKINO

\begin{abstract}
Laboratory of Veterinary Microbiology, Department of Veterinary Medicine, Obihiro University of Agriculture and Veterinary Medicine, Nishi 2-11, Inada-cho, Obihiro, Hokkaido 080-8555 Japan
\end{abstract}

\section{1.はじめに}

炭疽菌（Bacillus anthracis）が原因で起こる炭疽 (anthrax) は, 古くからヒトにも感染し重篤な症状を起 こす人畜共通感染症 (Zoonosis) であるが, 元来は草 食動物を中心に起こる，炭疽菌は人類史上最初に発見さ れた病原細菌である。19 世紀の中頃，羊や牛に炭疽の 流行が毎年のように繰り返されていたヨーロッパで, 2 人のドイッ人 (Pollender; 1885, Brauell; 1857) と フランス人（Delafond；1856）は，死獣の血液中に棒 状微小体を確認した. しかし, 炭疽菌を病原細菌第 1 号 として不動のものとしたのは, 固形培地での本菌の純培 養に成功したKoch（1876）である，このように炭疽菌 研究は近代微生物の基礎を築き, その発展に大きく貢献 した.

しかし，今年 10 月，アメリカの同時多発テロに引き 続き起こった炭疽菌によるテロ事件は世界中を震撼させ た.「貧者の核兵器」として 80 年も前から恐れられてき た生物兵器, それが現実社会に新たな恐怖を与えてしま ったのである。生物兵器として使用される可能性が高い ものとして，炭疽菌は天然痘とともにとりわけ注意を払 われてきた微生物である。

\section{2. 炭疽菌とは}

炭疽菌はBacillus 属のグラム陽性通性嫌気性桿菌で, 破傷風菌やボッリヌス菌と同じ土壤菌の一種である。 Bacillus 属の中で, 日和見感染を起こすものとしてB. subtilis, B. macerans, B. shaericusなどが知られてい るが，人間に病原性を有する菌種は細菌性伝染病の中で 最も毒力が強いものの一つである B. anthracis と食中毒 を起こすB. cereusのみである. 炭疽菌は大きさが 1.0 $\sim 1.2 \times 3 \sim 5 \mu \mathrm{m}$ の大桿菌で, 人工培地上では竹節状
の長い連鎖となる。鞭毛を欠き，血液寒天上では溶血を 示さない. 寒天培地上ではラフな集落を形成し, その辺 縁はちぢれ毛（メデゥサの首）状となるが，重曹添加の 固型培地を用いると 5 ～ $20 \%$ の $\mathrm{CO}_{2}$ 存在下で萊膜形成 を伴うムコイド状の光沢のある集落となる [4]. 一方， 生体内では菌体表層に萊膜形成を伴う単独もしくは短い 連鎖状であり，通常栄養形（vegetative form）として 存在する。しかし，栄養分が不足し増殖や分裂が起こり にくくなる環境下では，卵円形の芽胞体（spore）とな る。芽胞体は高温や低温, $\mathrm{pH}$, 消毒剂, 薬剂, 乾燥, 紫外線などに抵抗性が強く, 環境中で増殖せずに長期間 生残するが，栄養形は脆く死にやすい.

\section{3. 炭疽菌の感染サイクル}

炭疽菌の感染サイクルの中心である芽胞体が生体内に 侵入すると, マクロファージ内に速やかに取り込まれ発 芽（germination）する。発芽には適当な温度や $\mathrm{pH}$, 湿度，栄養源が必要である，発芽と同時に炭疽菌は増殖 し, 毒素によるマクロファージ融解が起き, 菌体は血流 へと放出される. その後, 病原因子の発現を伴いながら 炭疽菌は爆発的に増殖し, 産生毒素によるサイトカイン 産生が誘導され, 最終的に生体はショックにより死に至 る. 感染した動物の血液, 体液, 死体などが土壤や体表 を污染し, 空気に触れると, 栄養形はふたたび芽胞体に 戻り，野外に放出され，地表を污染する，炭疽菌はこの ような感染サイクルを繰り返し，炭疽污染地帯を作る (図 1) [5].

\section{4. 炭疽とは}

4-1. 動物の炭疽

炭疽は元来は牛などの草食動物の感染症であるが，炭 疽で死亡した死骸をあさる犬や肉食動物にも発生するこ

\footnotetext{
$\dagger$ 連絡責任者: 牧野壯一 (带広畜産大学畜産学部獸医学科家畜微生物学教室) 于 080-8555 北海道带広市稲田町西 2 線 11 $\mathbf{8 0} 0155-49-5386 \quad$ FAX 0155-49-5402
} 


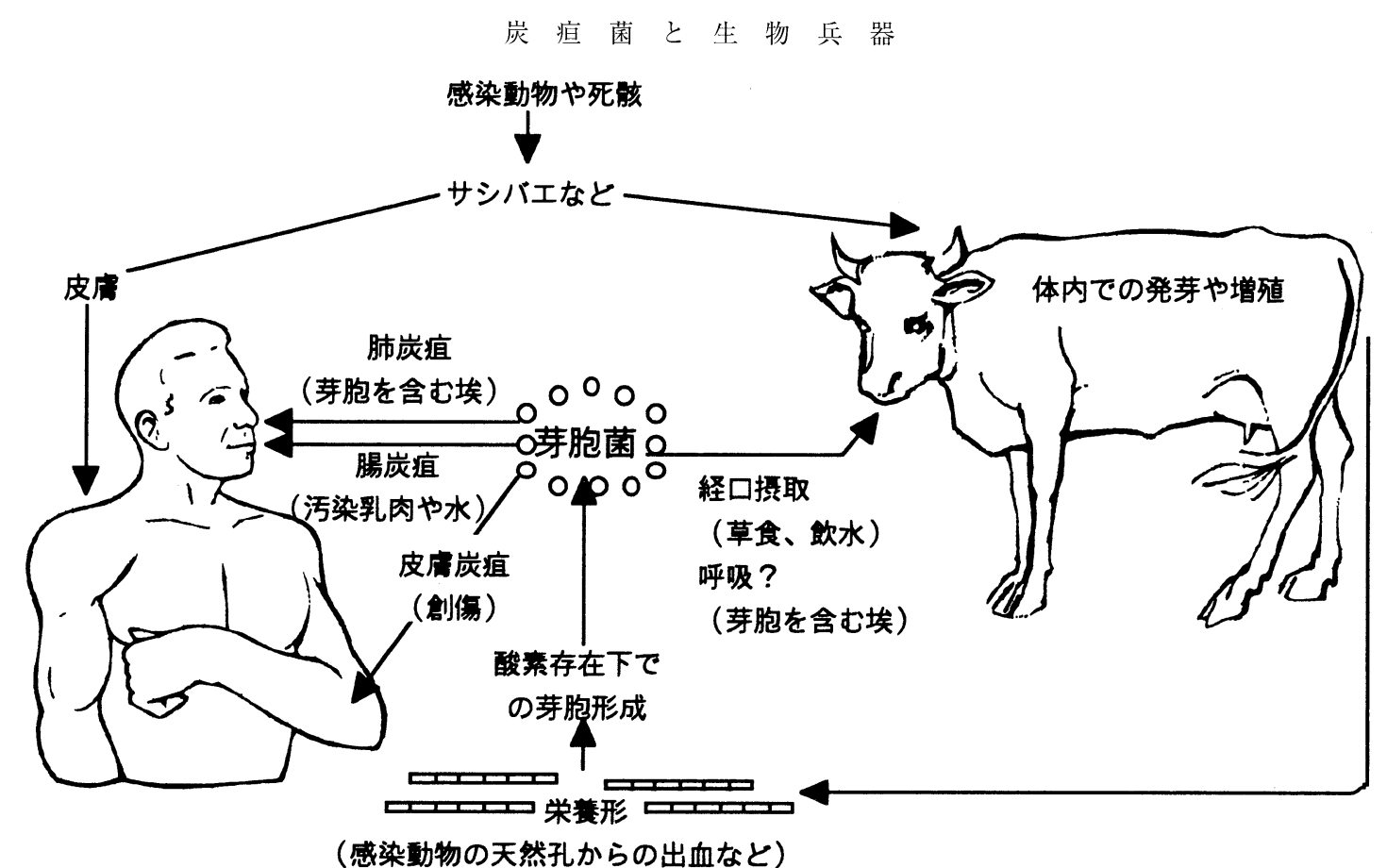

図 1 炭疸菌の感染サイクル（引用文献 [4] を改変)

とがある．動物によって炭疽菌に対する感受性は大きく 異なっているが, 炭疽菌の感染経路や動物の状態, 環境 条件など詳しく検討されておらず，いまのところ感染条 件や感受性についても厳密に議論されていない，たとえ ば，炭瘨菌の $\mathrm{LD}_{50}$ は，モルモットでは 1 以下であるが， カニクイザルでは約 3 である。また炭疽菌芽胞体のエア ロゾールでは, 羊でその MID (minimum infectious dose）は35,000 個程度，アフリカの自然公園のインパ ラでは 100 個程度と報告されている. しかし, 感受性が 低い豚では, $10^{7}$ から $10^{9}$ 個の芽胞体で発症する。

動物に扔ける炭疽の臨床症状は，草食動物において最 も重篤となり, 開口部からの出血や皮下出血を伴い急死 する。しかし，馬では発熱，一時的に呼吸困難や興奮状 態などが顕れる程度である。豚や肉食動物, 霊長類で は，顔や首の局所の浮腫，下顎や咽頭，腸間膜リンパ節 の腫れなどが顕れることがある。感受性の高い動物が死 亡する際には，血液 $1 \mathrm{~m} l$ あたり $10^{7} \sim 10^{8}$ 個程度まで炭 疽菌が純培養に近い状態で増殖する (敗血症).しかし, 詳細は不明だが，豚が炭疽で死亡する場合は血液 $1 \mathrm{ml}$ あ たり 100 個程度しか存在しない。

\section{4-2. ヒトの炭疽}

ヒトは炭疽に対して比較的抵抗力があるが，症状は感 染経路や種々の条件によって異なっている，ヒトの炭疽 は感染経路から皮虐炭瘨, 腸炭瘨, 肺炭疽の 3 種類に分 類される，皮虚炭疽は傷口等から皮下に芽胞体が侵入し 発症する，昆虫に咬まれて感染することもまれにある． 肺炭疽は埃や風によって芽胞体が気道感染し発症する. 腸炭疽は，炭疽菌に污染された肉や水を介して経口感染 により発症する．MID は肺炭疽の場合 8,000〜20,000
程度，腸炭疽の場合 1,000 個程度であるといわれてい る。

皮膚炭疽：ヒトの炭疽の自然感染例の $95 \%$ 以上が皮 膚炭瘨である。傷口などから菌体が侵入すると，2３ 日後にニキビ様の小さな丘疹が出現し，その $3 \sim 4$ 日後 にはリング状の水疮ができ，悪性膿胞が出現する。これ は冠状の黒色調の痂皮, 炎症性の浮腫を取り囲むように してあり, 無痛性で化膿しない。この黒色への変化が 「炭疽」の語源である。その中は萊膜を形成した菌体が 検出される，皮膚の痛みは伴わないが，痛みを伴う局所 リンパ節炎を併発することもある。さらに 5 ～７日で特 徵的なかさぶた（湤）ができ, 治療をしないと浮腫は拡 がり, 重症ではショック死する。炎傷の初期病変, 類丹 毒, 潰瘍, 梅毒性下疳などとの類症鑑別が必要である. 皮虐炭疽は比較的致死率は低いが，治療をしない時は $10 \sim 20 \%$ ，治療しても $1 \%$ 位が死の転帰をとるとされ ている.

腸炭疽：経口感染により起こる腸炭疽は一般的に腸管 に病変を起こすが，まれに咽頭部にも病変を起こすこと がある，腸管感染では吐き気，嘔吐，腹痛，吐血，血 便，そして腹水の貯留などが起き，治療をしないとショ ックを起こし死亡することもある，食中毒や血便を伴う 腸管感染症との類症鑑別が重要である。後者の場合は, 咽頭炎, 嚥下障害, 発熱, 頸部のリンパ節炎が起き, シ ヨックにより死亡する．治療しても約 $50 \%$ の死亡率で ある。連鎖球菌による咽頭炎や咽頭の腫瘍などとの臨床 鑑別が重要である. 腸炭疽の発生は通常まれであるが, 衛生環境や教育の不備な国で起こっている.

肺炭疽：初期症状はインフルエンザ様で, 軽度な発 


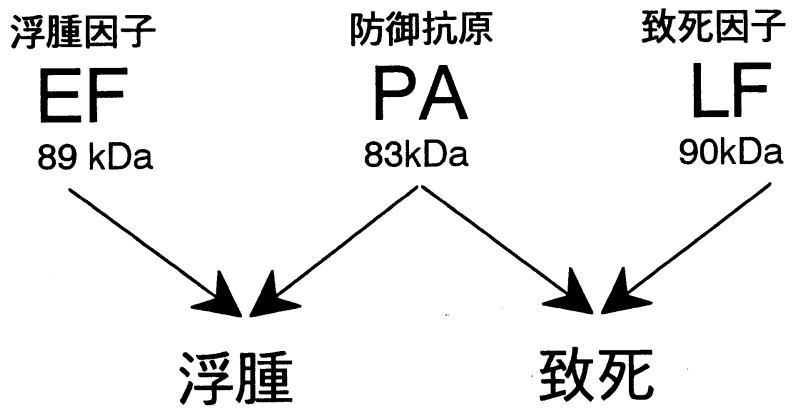

図 2 炭 疸 毒素成 分

熱, 疲労感, 倦怠感が数日続き, 頭痛, 筋肉痛, 悪寒, 発熱, そして胸部の軽度の疼痛が起きる. 重症では, 突 然の呼吸困難, チアノーゼ, 昏睡を伴う失見当識が起こ る. 治療が成功しない場合は 24 時間以内に死亡する.

また，炭疽菌性䯣膜炎が上記 3 種類の炭疽に引き続い て起こることがあるが，まれに初感染もある．治療して もほぼ100\%の死亡率となる。

\section{5. 炭痽の疫学}

世界各国で家畜および野生動物に扔いて地方病的発生 がみられる。わが国に打いては，昭和のはじめころま で，牛，馬を中心に年間数百頭の発生が記録されてい た.しかし, 家畜の飼養形態の変化や衛生管理技術の向 上により，その発生は急減し，この 10 年間においては, 1991 年抒よび 2000 年にそれぞれ牛での発生が 1 例，豚 に扔いては 1986 年以来報告がない.

1997 年オーストラリアのビクトリア地方で，9週間の 間に，202 頭の牛と 4 頭の羊の大きな発生があった。通 常個体から個体への直接的に伝播の低い炭疽にしては, 比較的大きな発生である. 当該地域では以前炭疽の発生 が報告されて扔らず，結局，污染源を特定することはで きなかった。

一方ヒトの炭疽の自然発生も世界各地で発生してい る. 一般的に炭疽は動物を扱う職業のヒトに発生が多い とされているが，獣疫の管理が不十分な国で多発する. わが国においては，ヒトの炭疽の発生はほとんど見られ ないが，1965 年，整死した炭疽牛に由来する集団発生 例があった。このとき 20 名にも及ぶ皮虐炭瘨（11名） および腸炭疽（9名）の患者が発生し，公衆衛生上大き な問題となった，炭疽は食肉検查所の検查でもっとも注 意がはらわれている疾病の一つであり, 食肉, 牛乳など に加工処理される前に発見处理されることが大切であ る。その後，1992 年と 1994 年にヒトで皮膚炭疽が 2 例 ゔつ報告されている，外国では日常的に発生するが，特 に中央・南アメリカ，アフリカ，アジアでは梁刻であ る。たとえば韓国では，2000 年に污染牛肉による腸炭 疽による死者が出ている。

\section{6. 炭疽菌の病原因子}

炭疽菌の病原因子としては, 毒素産生能と英膜形成能 の 2 つが知られている，毒素産生能は 3 種類の異なる蛋 白, 防御抗原 (protective antigen, PA; $83 \mathrm{kDa}$ ), 致 死因子 (lethal factor, LF; 90kDa), 浮腫因子 (edema factor, EF； 89kDa）から成っている. LF と EF が毒素 の本体であるが，単独では毒性を示さず，PAの存在が 不可欠である（図2）。また，多くの病原菌では多糖体か ら成っているのとは異なり, 炭疽菌の萊膜は, D-グル タミン酸のホモポリペプチドから成っている，両者の遺 伝子支配は，それぞれ強毒株の持つ 182 および 96 キロ ベースの大プラスミドによる，それぞれのプラスミド が，炭疽の病原性に必須であることが証明されており， どちらかが脱落すると毒力が減弱する，パスッールによ って作られた炭疽菌の弱毒ワクチン株は, 萊膜形成プラ スミドの脱落変異株であった.

毒素の細胞内侵入過程は特徵的で，まず，PAが大半 の動物細胞上の存在するレセプターに結合する [3]．こ のレセプターが最近同定されている。結合したPAは， 細胞表層のプロテアーゼであるフリン（furin）などに より 1 個所で切断され，細胞表層に結合状態の $63 \mathrm{kDa}$ （PA63）と細胞表層から遊離する20kDa（PA20）の 2 つに分かれる，PA63は，LFまたは EF と結合しオリゴ マーを作り，細胞内に取り込まれ，細胞に障害を与え る。このシステムを利用して，遺伝子組換え技術により キメラ蛋白を作成して, 生理活性物質の細胞内導入やワ クチン開発への応用が期待されている $[1]$.

一方，炭疽菌の萊膜は，免疫学的には“納豆のネバネ バ”と同一であり，宿主による免疫機構，特に貪食作用 から菌体を守る働きをしていると考えられている.

\section{7. 生物兵器としての炭疽}

\section{$7-1$. 生物兵器の歴史 $[2]$}

史上最初の生物兵器の使用は, 第一次世界大戦中に動 物に対して行われたと報告されている. その後，ジュネ ーブ条約にもかかわらず，多くの国が第一次，第二次世 界大戦の間に, 生物兵器の研究を行った。1943 年にア メリカでは，他からの攻撃に応じる場合を除き，生物兵 器を使用しないと宣言した。また，英国では，炭疽菌を 用いた生物兵器を実験したことがあるが，現在のとこ ろ，わが国が世界で唯一，第二次世界大戦中にペスト菌 による生物兵器を使用したことで知られている。

冷戦時代には，核兵器に焦点が当てられたが，1969 年アメリカは旧ソ連に対し, 生物兵器プログラムの保有 を宣言していた。1972年の生物学拉よび毒素兵器の会 議では，140力国以上が，生物兵器による脅威をなくす ことに合意した．しかし，旧ソ連では，研究開発が続け 
表 1 化学片と比較した生物剤の特徵

\begin{tabular}{|c|c|c|}
\hline & 生物剂 & 化学剂 \\
\hline 影響 & 遅 & 即 時 \\
\hline 攻 撃 の 認 知 & 遅 & 早 い \\
\hline 揮 発 性 & な & あり \\
\hline 皮膚污染の影響 & 原則無害 & 有 害 \\
\hline 犠牲者の分布 & 分 散 & 集 中 \\
\hline 除染の必要性 & 小さい & 必 須 \\
\hline
\end{tabular}

られたのである. その後, 旧ソ連では, 兵器工場から炭 疽菌が空気中に放散され，少なくとも 68 名が死亡した という事故が 1979 年に起こっている. 現在でも大量の 生物兵器を開発・保有している国があると考えられてい る.わが国では，1995 年の某宗教団体により炭疽菌や ボッリヌス毒素が実際に散布されていたといわれてい る.

\section{7-2. 炭疽菌の生物兵器としての利点}

生物兵器として使用される微生物は，(1)簡単にヒトか らヒトへ拡散, 伝播する, (2)高い死亡率, (3)パニックや 社会の混乱を引き起こす，(4)公衆衛生上影響が大きい, などの特徵を持ち, 安定性, 感染性・伝染性, 毒性・治 療抵抗性, 大量生産性, エアロゾル化可能がその効果を 増強させる．これらに最も合致するのが炭疽菌の芽胞体 である.さらに, 炭疽芽胞体は「唃者の核兵器」と呼ば れるが，安価で大量精製可能である。たとえば， $1 \mathrm{~km}^{2}$ 当たりの有害化にかかるコストは通常兵器が 2,000 ド ル, 核兵器が 800 ドル, 化学剂が 600 ドルかかるとした ら，生物剤はたった 1 ドルで済むのである. 同時に表 1 に示したように，知らないうちに兵器として使用され， 発症までに時間がかかるので生物兵器として検知するこ ろには犯人は逃げてしまうという利点もある，まさに目 に見えない恐怖こそが生物兵器なのである。

7-3. 炭疽菌による生物テロのシナリオ

アメリカでは以前から炭疽芽胞体を用いた最悪のシナ リオが想定されて, 生物兵器への対処が為されてきた。 たとえば，ボストン上空 1 万フィートから炭疽芽胞体を 散布した場合，翌日には 36 名が非特異的症状を発現し， 2 日後には 5,000 名が呼吸困難症状を呈し，3 日後にな って炭瘨のバイオテロの疑いが強くなってきたときに は，5,000 名死亡し，26,000 名が重症，30,000 名が軽症 となっている。さらには, その翌日には 22,000 名が死 亡, 162,000 名が発症, 翌々日には72,000 名が死亡, 200,000名が発症するだろうと考えられている.

炭疽菌は安価な培地を用いて比較的容易に大量培養が でき，芽胞体形成も容易である。しかも芽胞体の乾燥品 として長期間安定であり，持ち運びが非常に楽である。 炭疽菌の芽胞体 $100 \mathrm{~kg}$ の乾燥品は, ヒトの $\mathrm{LD}_{50}$ 量の約 $10^{13}$ 倍に相当する. 技術的や経済的に低い国でも攻撃用
の兵器として作りやすく，ある限定された地域にヒトに も動物にも甚大な被害を与えることが容易にできる炭疽 菌の生物兵器はヒトの愚かさの象徵であるといえる。確 かに大学で簡単な微生物を扱ったヒトにとっては，比較 的容易に炭疽菌を大量に培養可能ではあるが，感染力を 持つ微粒子の乾燥芽胞を作るのは相当の技術，設備が必 要である。すなわち，1〜 $5 \mu \mathrm{m}$ の大きさが肺に感染し やすく，しかも空中での滞留時間が長く，この大きさに 加工する技術が最も重要であり技術力が必要とされるの である。

\section{8. 炭疽の予防や防御}

炭瘨の自然発生を予防するには，炭疽を発症した動物 を的確に淘汰し, 污染物の的確な廃棄や殺菌, 感受性動 物のワクチン接種, 感染の可能性のある人間へのワクチ ン接種が最も効果がある防御方法である.

動物に対するワクチンは無莢膜変異株の芽胞体菌の $50 \%$ グリリン加生理食塩水内にアジュバントとして $0.5 \%$ サポニンが加えられたものがわが国では用いられ ている.しかし，この株は完全に非病原株であるとはい えず，羊やラマなどには毒力を保持している．また，防 御効果は約 1 年は継続するので, 発生地域ではブース夕 一が必要である，一方ヒトに対するワクチンは，中国や ロシアでは動物同様芽胞体による生ワクチンが使用され ているが，一般的には，萊膜非産生，毒素産生株の上清 の明攀沈殿物や水酸化アルミニウム沈殿物が用いられて いる．しかしヒトへのワクチンは長期間必要であり，副 作用もあり，特殊な場合を除いては一般市民には用いら れていない。たとえばアメリカの場合，ワクチン接種は 2 週間ごとに 3 回皮下注射し，その後，6，12，18 力月 後に計 3 回皮下接種，次に 1 年おきにブースター接種を 皮下に行うよう決められている，そのため，もっぱら動 物に対するワクチンにより炭疽を減らそうとしているの が現状で，ヒトへの効果的で副作用の少ない新しいワク チン開発も行われている。しかし，テロリズムを想定し た効果的な予防方法は現在のところないが，炭疽菌に暴 露された近郊では予防的に抗生物質投与が行われる.

\section{9. 炭疽の抗生物質による治療}

炭疽菌は一般的にペニシンに対して感受性があるの で，ペニシリンが第一選択肢として使用される．200万 単位のペニシリンを 2 時間ごと静脈内注射するが，その 他テトラサイクリンやエリスロマイシンも使える．耐性 菌を考慮すると，シプロフロキサシン $(400 \mathrm{mg}$ の 8 12 時間ごと静注）やドキシサイクリン（初回 $200 \mathrm{mg}$, その後 12 時間ごとに $100 \mathrm{mg}$ 静注）がアメリカでは用い られている．ただしこの濃度はアメリカ人を想定したも ので，わが国でそのまま適応できるか不明である。ま 
た，シプロフロキサシンは 2001 年 11 月現在保健薬の適 応を受けていない。ショックの回避や補液, 酸素吸入な どの対症療法も必要である。また, 治療や検死中に使用 した場所や器具などは, 芽胞体の除染が必要である. 消 毒薬としては, ホルマリンや次亜塩素酸などを殺菌濃度 で使用するが，次亜塩素酸は有機物の存在で活性が低下 する. 過酸化水素水や過酢酸も効果がある.

$$
\text { 7.お りに }
$$

1857 年コッホが炭疽菌を病原菌として同定して以来 1 世紀半が経とうとしている。この間, 炭疽菌は, 病原菌 の持つあらゆる面を経験して今日にいたっている．炭疽 菌の病原因子の一つが萊膜であることは，1908年に報 告されている. パスツールが弱毒ワクチン株を作製し て，十数年経った頃である。 それに遅れること, 約 20 年後, 炭疽菌の毒素の存在が報告された，その他の病原 因子が同定されてはいるが，おもな病原因子は今なお萊 膜と毒素である，単純な因子であると思われるのに，そ の働きについてはずっと不明のままであった。しかし， この $1 \sim 2$ 年, 炭疽菌の発症機構の基礎研究が進展し始 め, 両病原因子とも複雑な機構を持っていることが明ら
かとなってきている. 病気としてはもう古いという見方 もあるが，宿主－寄生体の関係からみると，まだまだ興 味深い点が少なくない, その一方で, 炭疽茵は生物兵器 の最有力候補として長く脅威の的であった. その脅威が まさにアメリカで現実に起こってしまった．化学・核兵 器と異なり見えない脅威である生物兵器にわれわれはど のように立ち向かえばよいか，真剣に考えなければいけ ない時代になったのかもしれない.

\section{引用 文 献}

[1] Hanna, PC, Acosta, D, Colllier, RJ : Proc Natl Acad Sci USA, 90, 10198 (1993)

[2] Inglesby TV, Henderson DA, Bartlett JG, Ascher MS, Eitzen E, Friedlander AM, Hauer J, McDade J, Osterholm MT, O’Toole T, Parker G, Perl TM, Russell PK, Tonat K : JAMA, 281, 1735-1745 (1999)

[3] Bradley KA, Mogridge J, Mourez M, Collier RJ, Young JAT : Nature, 414, 225-229 (2001)

[4] Makino, S, Sasakawa, C, Uchida, I, Terakado, N, Yoshikawa, M : Mo1 Microbiol, 2, 371-376, (1988)

[5] Turnbull PCB : Guidelines for the Surveillance and Control of Anthrax in Humans and Animals, World Health Organization (1998)

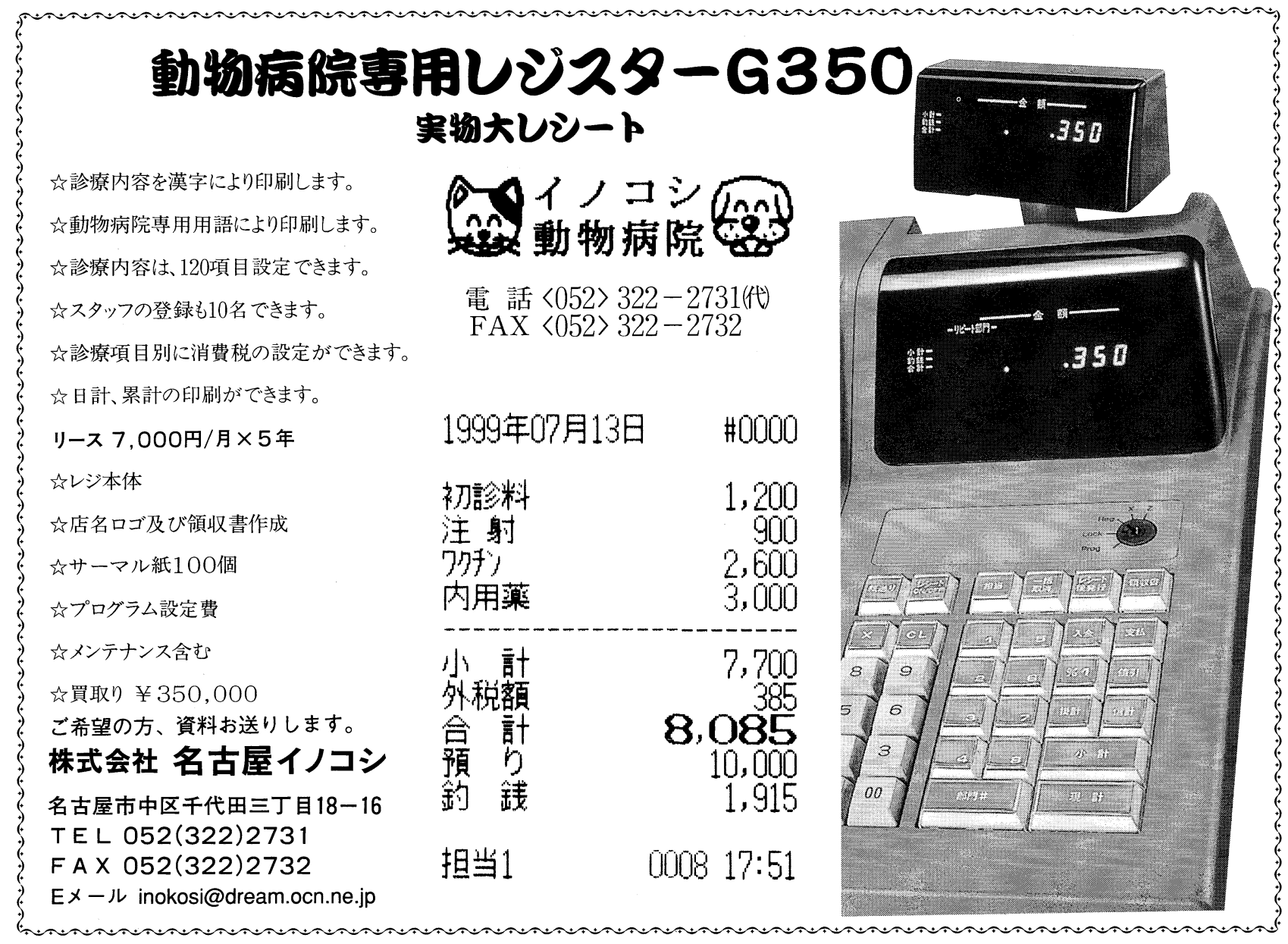

